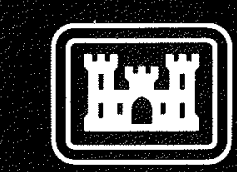

US Army Corps of Englneers
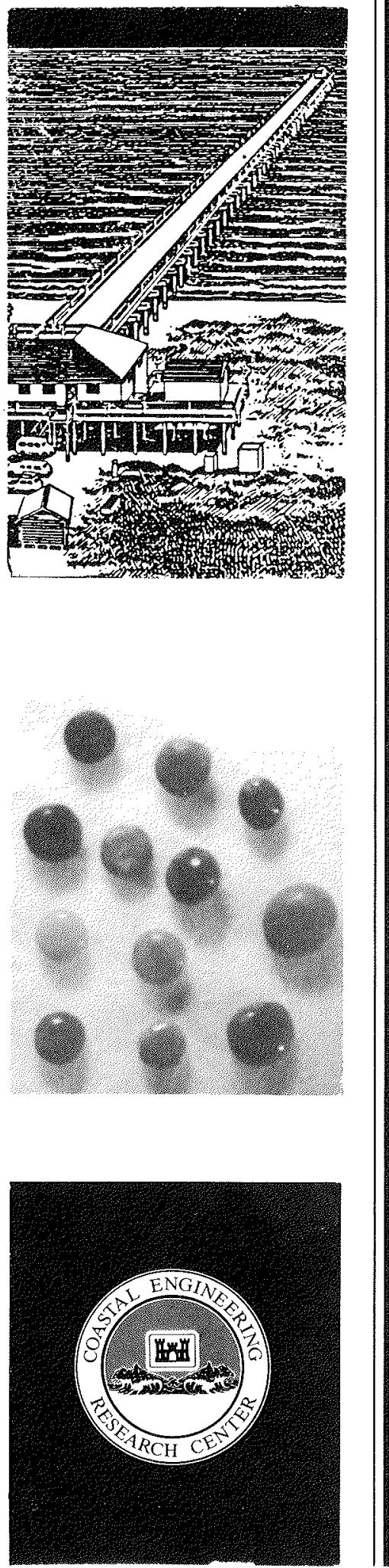

\title{
OOLITES AS A NATURAL TRACER IN BEACHES OF SOUTHEASTERN FLORIDA
}

by

\author{
Edward P. Meisburger
}

Coastal Engineering Research Center

DEPARTMENT OF THE ARMY

Waterways Experiment Station, Corps of Engineers

PO Box 631, Vicksburg, Mississippi 39181-0631

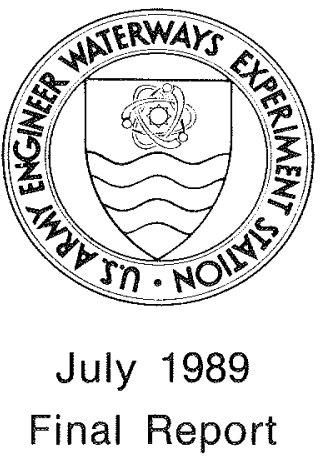

Approved For Public Release; Distribution Unlimited

Prepared for DEPARTMENT OF THE ARMY US Army Corps of Engineers Washington, DC 20314-1000

Under Barrier Island Sedimentation Studies Work Unit 31665 
Destroy this report when no longer needed. Do not return it to the originator.

The findings in this report are not to be construed as an official Department of the Army position unless so designated by other authorized documents.

The contents of this report are not to be used for advertising, publication, or promotional purposes. Citation of trade names does not constitute an official endorsement or approval of the use of such commercial products. 
Unclassified

SECURITY CLASSIFICATION OF THIS PAGE

\begin{tabular}{|c|c|c|c|c|}
\hline \multicolumn{4}{|c|}{ REPORT DOCUMENTATION PAGE } & $\begin{array}{l}\text { Form Approved } \\
\text { OMB No o704.0188 } \\
\text { Exp. Date Jun } 30,1986\end{array}$ \\
\hline \multicolumn{2}{|l|}{$\begin{array}{l}\text { 1a REPORT SECURITY CLASSIFICATION } \\
\text { Unclassifled }\end{array}$} & \multicolumn{3}{|l|}{ 1b. RESTRICTIVE MARKINGS } \\
\hline \multicolumn{2}{|l|}{ 2a. SECURITY CLASSIFICATION AUTHORITY } & \multicolumn{3}{|c|}{$\begin{array}{l}\text { 3. DISTRIBUTIONIAVAILABILITY OF REPORT } \\
\text { Approved for public release; } \\
\text { distribution unlimited. }\end{array}$} \\
\hline \multicolumn{2}{|c|}{$\begin{array}{l}\text { 4. PERFORMING ORGANIZATION REPORT NUMBER(S) } \\
\text { Misce1laneous Paper CERC-89-10 }\end{array}$} & \multicolumn{3}{|c|}{ 5. MONITORING ORGANIZATION REPORT NUMBER(S) } \\
\hline $\begin{array}{l}\text { 6a. NAME OF PERFORMING ORGANIZATION } \\
\text { USAEWES, Coastal EngIneering } \\
\text { Research Center }\end{array}$ & $\begin{array}{l}\text { 6b. OFFICE SYMBOL } \\
\text { (If applicabie) }\end{array}$ & \multicolumn{3}{|c|}{ 7a. NAME OF MONITORING ORGANIZATION } \\
\hline \multicolumn{2}{|l|}{$\begin{array}{l}\text { 6c. ADORESS (City, State, and IIP Code) } \\
\text { PO Box } 631 \\
\text { Vicksburg, MS } 39181-0631\end{array}$} & \multicolumn{3}{|c|}{ 7b. ADORESS (City, State, and ZIP Code) } \\
\hline \multicolumn{2}{|l|}{$\begin{array}{l}\text { 8a. NAME OF FUNDING/SPONSORING } \\
\text { ORGANIZATION } \\
\text { US Army Corps of Engineers }\end{array}$} & \multicolumn{3}{|c|}{ 9. PROCUREMENT INSTRUMENT IDENTIFICATION NUMBER } \\
\hline \multirow{2}{*}{\multicolumn{2}{|c|}{$\begin{array}{l}\text { 8C. ADDRESS (City, State, and ZIP Code) } \\
\text { Washington, DC 20314-1000 }\end{array}$}} & \multicolumn{3}{|c|}{ 10. SOURCE OF FUNDING NUMBERS } \\
\hline & & $\begin{array}{l}\text { PROGRAM } \\
\text { ELEMENT NO. }\end{array}$ & $\begin{array}{l}\text { TASK } \\
\text { NO. }\end{array}$ & \begin{tabular}{|} 
WORK UNIT \\
ACCESSION NO \\
31665
\end{tabular} \\
\hline
\end{tabular}

11. TITLE (include Security Classification)

Oolites as a Natural Tracer in Beaches of Southeastern Florida

12. PERSONAL AUTHOR(S)

Meisburger, Edward P.

\begin{tabular}{|c|c|c|c|}
\hline $\begin{array}{l}\text { 13a. TYPE OF REPORT } \\
\text { Fina1 report }\end{array}$ & $\begin{array}{l}\text { 3b. TIME COVERED } \\
\text { FROM TO }\end{array}$ & $\begin{array}{l}\text { 14. DATE OF REPORT (Year, Month, Day) } \\
\text { July } 1989\end{array}$ & $\begin{array}{c}\text { 15. PAGE COUNT } \\
29\end{array}$ \\
\hline
\end{tabular}

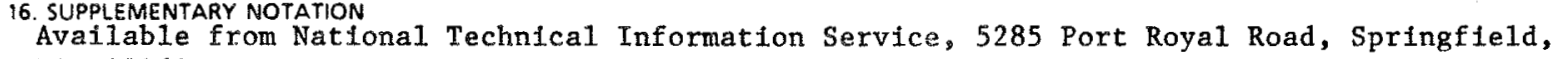
VA 22161 .

\begin{tabular}{|c|c|c|c|}
\hline 17. & \multicolumn{2}{|c|}{ COSATI CODES } & \multirow{3}{*}{$\begin{array}{l}\text { 18. SUBJECT TERMS (Continue on reverse if necessary and identify by block number) } \\
\text { Beaches -Florida } \\
\text { Oolite } \\
\text { Sediments (Geology) }\end{array}$} \\
\hline FIELD & GROUP & SUB-GROUP & \\
\hline & & & \\
\hline
\end{tabular}

19. ABSTRACT (Continue on reverse if necessary and identify by block number)

Calcareous oolites occur in beach and continental shelf sediments from Cape Canaveral, Florlda, to as far south as Palm Beach. The abundance of oolites in both shelf and beach sediments is highly irregulax. In beach sediments the oolites tend to be significantiy more abundant in backshore deposits than in foreshore deposits. This abundance is believed to be due to selective sorting with the oolites responding to flow as heavier particles because of their shape and surface smoothness. The source of the oolites in the beach deposits appears to be the inner continental shelf. Because of their highly irregular distribution and sensitivity to selective sorting processes, 1 t is concluded that quantitative estimates of the total amount of sediment transported ashore with the oolites cannot be made.

\begin{tabular}{|c|c|c|c|}
\hline $\begin{array}{l}\text { 20. DISTRIBUTION/AVAILABILITY OF ABSTRACT } \\
\text { Q UNCLASSIFIEDIUNLIMITED } \square \text { SAME AS RPT. }\end{array}$ & $\square$ DTK USTERS & $\begin{array}{l}\text { 21. ABSTRACT SECURITY CLASSIFICAT } \\
\text { Unclassifled }\end{array}$ & \\
\hline 22a. NAME OF RESPONSIBLE INDIVIDUAL & & 22b TELEPHONE (Inciude Area Code) & $22 c$ \\
\hline
\end{tabular}

DD FORM 1473, 84 MAR

83 APR edition may be used until exhausted. All other editions are obsolete.
SECLRITY CLASSIFICATION OF THIS PAGE

Unclassified 
This report is the result of research carried out at the US Army Engineer Waterways Experiment Station (WES) at the Coastal Engineering Research Center (CERC), under Barrier Island Sedimentation Studies Work Unit 31665 , Shore Protection and Restoration Program of the US Army Corps of Engineers (USACE). USACE Technical Monitors for this research were Messrs. John H. Lockhart, Jr., John G. Housley, James E. Crews, and Charles W. Hummer.

The study was conducted by personnel of CERC under the general direction of Dr. James R. Houston, and Mr. Charles C. Calhoun, Jr., Chief and Assistant Chief, CERC, respectively; and under direct supervision of Mr. H. Lee Butler, Chief, Research Division. This report was prepared by Mr. Edward P. Meisburger, Coastal Geology Unit, Coastal Structures and Evaluation Branch, Engineering Development Division, CERC, and edited by Mrs. Nancy Johnson, Information Technology Laboratory, under the Inter-Governmental Personnel Act.

LTC Jack R. Stephens was Acting Commander and Director of WES during report publication. Dr. Robert $W$. Whalin was Technical Director. 


\section{CONTENTS}

PREFACE ..........................................

PART I: INTRODUCTION ...............................

Previous Studies...................................

3

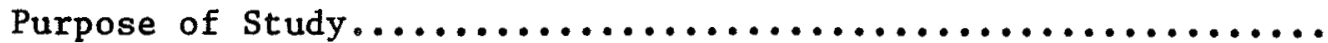

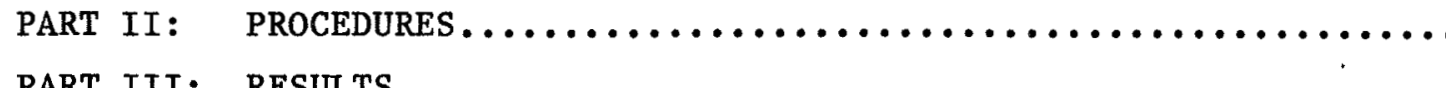

$$
\text { PROCEDURES. }
$$

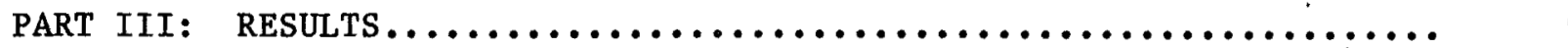

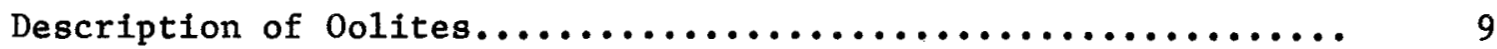

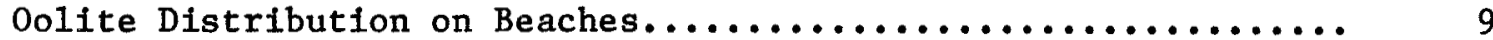

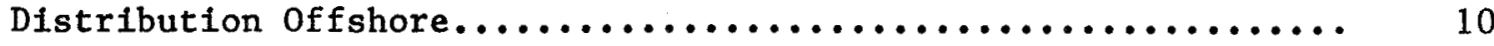

PART IV: DISCUSSION............................... 11

Distribution of $0 o 1 i t e s . \ldots \ldots \ldots \ldots \ldots \ldots \ldots \ldots \ldots \ldots \ldots \ldots \ldots \ldots \ldots \ldots$

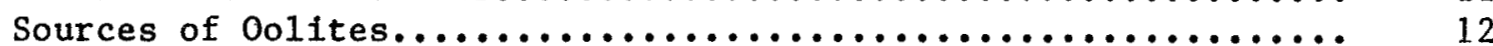

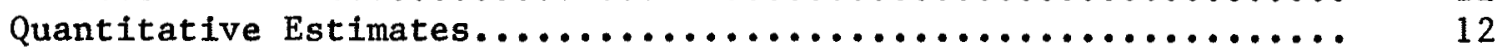

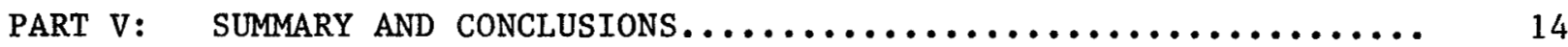

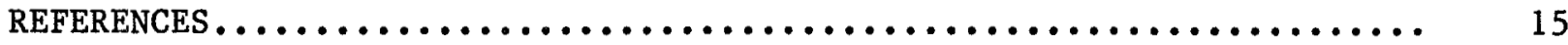

TABLES $1-5$ 
OOLITES AS A NATURAL TRACER IN BEACHES

OF SOUTHEASTERN FLORIDA

\section{PART I: INTRODUCTION}

\section{Previous Studies}

1. Calcareous oolites in inner continental shelf and beach sediments of the central Florida Atlantic coast were studied by Pilkey and Field (1972) and Field and Duane (1974). The investigation proved that oolites occurred in inner shelf and beach sediments from the southern study limit at Vero Beach to False Cape on the northern shore of Canaveral Peninsula (Figure 1). North of False Cape no oolites in either inner shelf or beach deposits was found. It was concluded that although oolites occur on the central and outer shelf of this region as reported by Terlecky (1967), Pilkey et al. (1969) and Macintyre and Milliman (1970), the oolites found in the beach sediments probably originated closer to shore in outcrops of oolitic Pleistocene calcareous rock which underlies the inner shelf.

2. The presence of oolites in the beach sand led Pilkey and Field (1972) to conclude that in the region under study there is onshore movement of sediment from the inner shelf to the adjacent shore. It is believed that this movement is frequent enough to continuously replenish the oolites in the beach despite their high attrition rate in the turbulent beach and nearshore environment.

\section{Purpose of Study}

3. The evidence of onshore movement of inner continental shelf sediment presented by Pilkey and Field (1972) and Field and Duane (1974) for the Florida coast is of significance to Coastal Engineering because it indicates a potentially important sediment source of central Florida Atlantic coast beaches and is an example of a process that may be widespread (Giles and Pilkey 1965, Meza and Paola 1977, Pizzuto 1986, and Williams and Meisburger 1987).

4. There are two main purposes for this study. The first is to present 


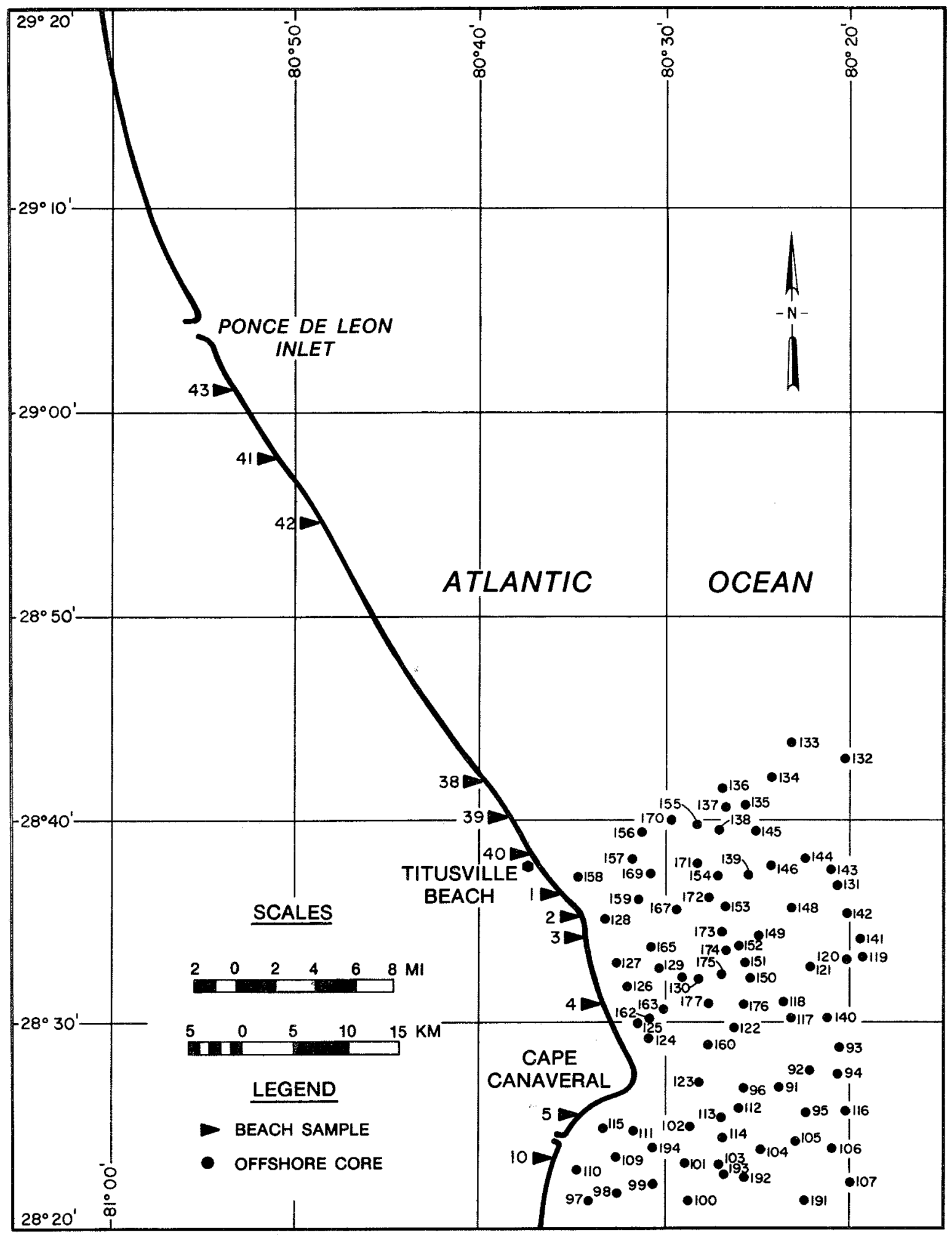

Figure 1. Location of cores and beach samples (Sheet 1 of 3 ) 


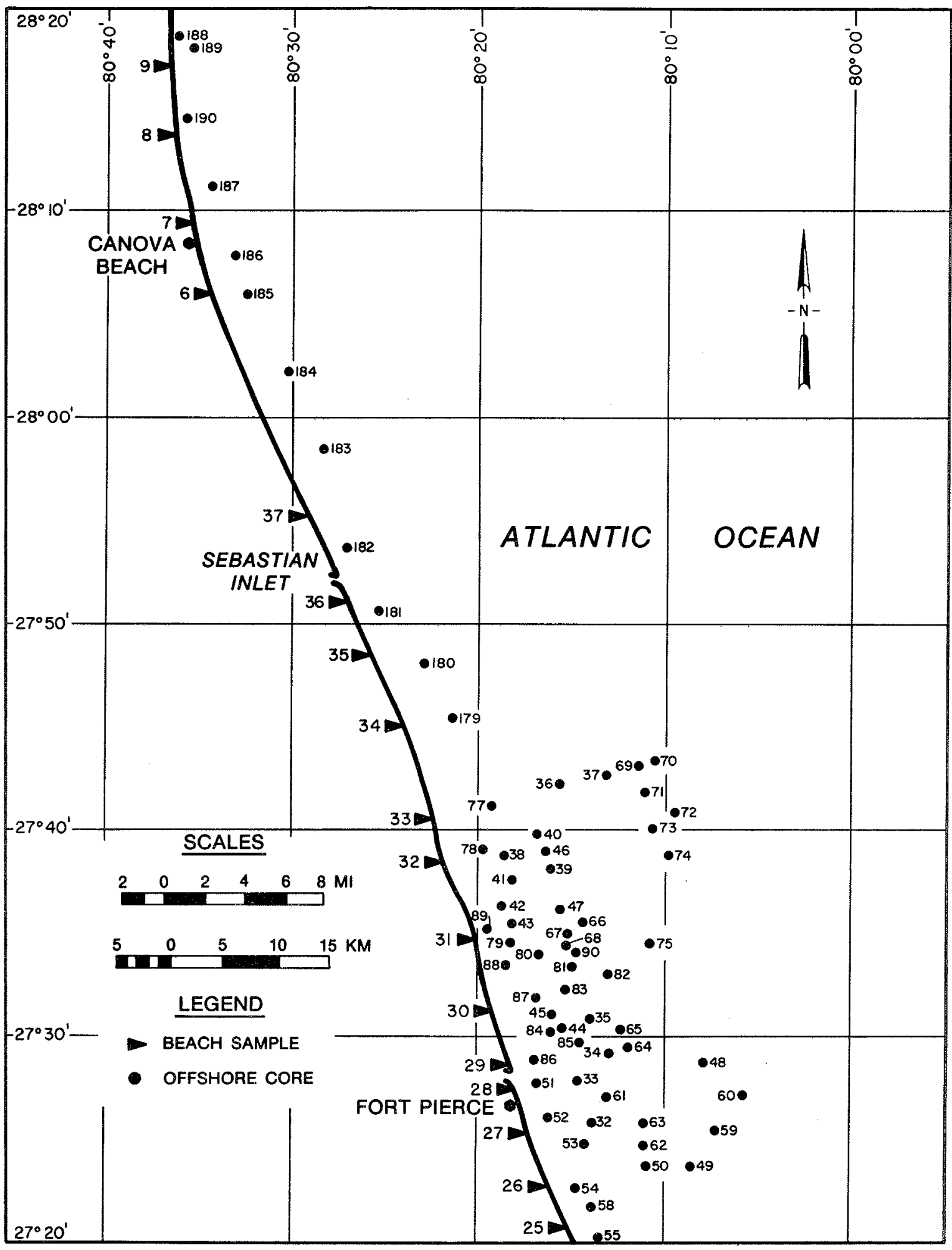

b. Central part of study area

Figure 1. (Sheet 2 of 3 ) 


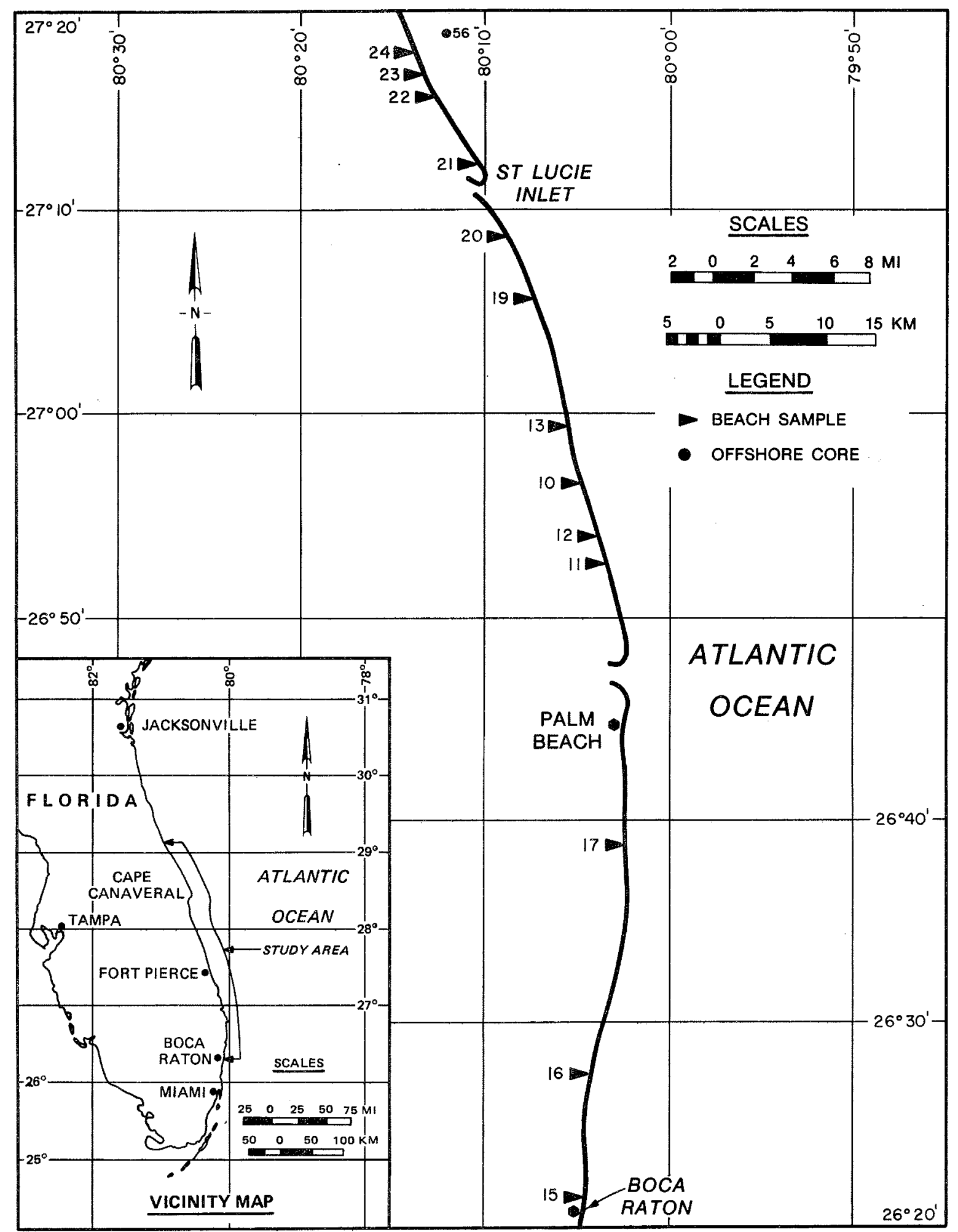

c. Southern part of study area

Figure 1. (Sheet 3 of 3 ) 
data on oolite occurrence south of the area studied by Pilkey and Field (1972) and Field and Duane (1974) that indicates onshore movement of sediments may occur at least as far south as Palm Beach, Florida.

5. The second purpose of this study is to estimate, if possible, the amount of sediment being transported onshore with the oolites and thus the significance of the inner shelf contribution to the sediment budget of southern Florida Atlantic beaches. An estimate could be made by determining the ratio between the non-oolitic and oolitic particles of a given size class in the source area. The ratio could then be applied to the oolite frequency in the beach deposits to calculate the total contribution from the inner shelf. This procedure is discussed in this report.

6. Calcium carbonate oolites have a specific gravity range of approximately 2.7 to 2.9 which is close to the predominant quartz (SG 2.7) and shell fragments of the sediment matrix. Therefore, it seems likely that they would tend to maintain their proportional relationship during transport and deposition. This is not the case with the heavy minerals, the most often used natural tracer. Heavy minerals have specific gravities considerably higher than those of quartz and shell fragments; consequently, they are prone to selective sorting processes. This alters their proportional relationship to the sediment matrix during transport and deposition. 
PART II: PROCEDURES

7. All offshore samples were obtained from the CERC Inner Continental Shelf Study (ICONS) programs cores taken off the central and southern Atlantic coast of Florida (Figure 1). Basic ICONS reports on these areas are in Meisburger and Duane (1971) and Field and Duane (1974). Samples containing surficial sediment were primarily used for this study. In addition, a number of downhole samples were secured to check oolite distribution with depth.

8. Beach samples were obtained during field trips to the Florida coast in 1981 and 1982. An attempt was made at each site to collect five samples distributed as follows: (a) at the turbulent meeting of the backrush and incoming wave; (b) at the limit of existing uprush; (c) at the berm crest or high-water mark in absence of a berm; (d) on the backshore; and (e) from a hole in the backshore, approximately $18 \mathrm{in.}(45 \mathrm{~cm})$ deep. In many cases, a full suite of samples was not obtained because the beach had no backshore.

9. Samples were washed on a $0.063-\mathrm{mm}$ sieve to clean the material and remove fines. The 0.250 to $0.425-\mathrm{mm}$ sieve fraction was used for determination of oolite concentration because the bulk of oolites present was in this size range. The sample was placed on a gridded counting tray and viewed under a binocular microscope where the number of oolites in the sample could be determined. Since it was necessary to use large amounts of sample to obtain statistically significant counts, it was impractical to count the total grains in the sample. Consequently, the same weight was used and all abundance data reduced to oolites per standard sample weight of $0.25 \mathrm{~g}$.

10. A test of the repeatability of this procedure was conducted by counting oolites in sets of five $0.10-\mathrm{g}$ subsamples of several typical samples. The results indicated that the values for each subsample of a set were within 15 percent of the average value for the set. Thus it is 1ikely that, at a maximum, differences of 30 percent or more between any two samples probably indicate actual differences in oolite distribution, while differences of less than 30 percent may or may not be due to random factors unrelated to actual distribution. The relative differences in oolite abundance for samples used in this study are for the most part large enough that they probably reflect actual differences in distribution. 


\section{Description of Oolites}

11. Oolites found in the study area are variable in shape and color (Figure 2). The most distinctive and common single shape is the form of a capsule with straight sides, rounded ends, and a round cross section. Other distinctive shapes are subspherical and in the form of columns, eggs, and buttons. Many of the oolites are nondescript shapes that are too variable to classify. These are probably not fully formed and still reflect the shape of the nucleus. Oolite colors are varieties of white, gray, and brown. Gray is the most common color with frequent bluish and greenish hues.
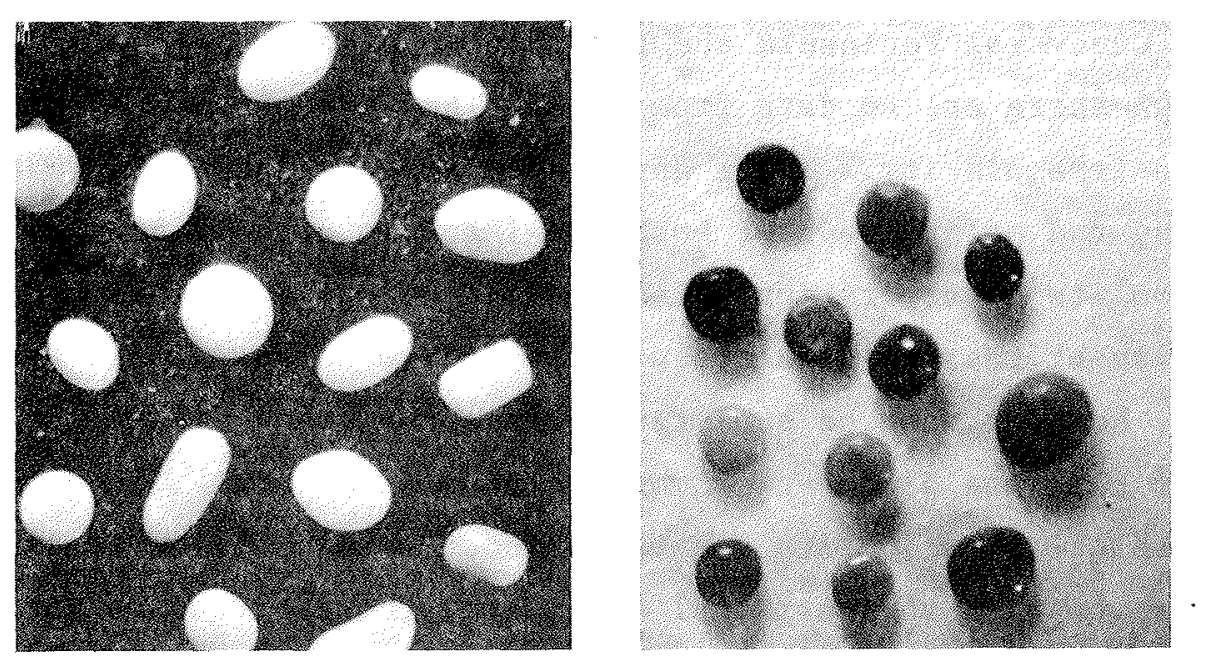

Figure 2. Typical oolites from the study area (modification 20X)

12. A number of oolites have partly exposed nucleui because of incomplete formation or breakage. The most common nuclear material seen in these oolites is comprised of particles of quartz.

\section{Oolite Distribution on Beaches}

13. Table 1 shows the oolite counts for beach samples taken between Site 15 near Boca Raton in the south to Site 43 near Ponce de Leon Inlet in the north. The sites are arranged in actual sequence of their occurrence from 
south to north and not in strict numerical order.

14. A comparison of data in Table 1 shows two significant trends. One is that oolites are comparatively common in beach deposits between Boca Raton and Site 5 a few miles south of Cape Canaveral and rare or missing from samples taken north of the cape beginning with beach sample 4 (Figure 1c). A second important trend is a pronounced difference in the concentration of oolites between backshore samples (berm, backshore, and hole) and foreshore samples (backrush and uprush) at most sites. In many cases, the oolite concentration on the backshore exceeds the foreshore concentration by a factor of five or more.

\section{Distribution Offshore}

15. Tables 2 and 3 show oolite frequency in samples from offshore locales in the Canaveral Peninsula and Fort Pierce areas. All core numbers are shown although there are no data from some. These counts are typified by their extreme irregularity. There appears to be no relationship between bottom topography and oolite counts; both shoal and intershoal samples are highly variable in oolite concentration. Sediment lithology also does not appear to be a factor except that oolites are usually sparse in the finest grained sediments. This, however, can be expected because the grain sizes of these deposits are finer than the diameter of most oolites.

16. Table 4 shows oolite counts for core samples below the surficial layer. In common with the surficial sediments, there often are large differences between samples. The differences tend to be less when the downhole samples are of the same lithology as the surficial sediment, but these, too, differ considerably in several cases. 
PART IV: DISCUSSION

Distribution of 0olites

17. As previously stated, backshore deposits on the beaches contain significantly higher concentrations of oolites than foreshore deposits. A similar trend frequently occurs with heavy minerals which tend to be more numerous in backshore deposits of the study area than in foreshore deposits. The study suggests that oolites behave in transport like particles heavier than the predominant quartz and shell particles of similar size.

18. To further test this assumption, a simple test was made by the following procedure. A number of representative samples was selected, and two subsamples of each sample were taken. The number of oolites per unit weight was determined for subsample 1. Subsample 2 was placed in a 16-in. gold pan and panned until only a small heavy residue of less than $1 \mathrm{~g}$ remained. The number of oolites per unit weight in the residue was then determined. A comparison of results is shown in Table 5. In all cases, oolites were significantly more abundant in the heavy residue of subsample 2 .

19. The reason for the higher oolite and heavy mineral content of backshore deposits is likely related to the fact that most backshore deposition occurs during storms when waves and currents have increased ability to carry larger and heavier particles. Wind deflation of backshore sediment also has an effect by winnowing the more transportable particles and further concentrating the relatively heavy particles. Although oolites have a specific gravity near that of the quartz and shell fragments that make up most of the beach sediment, it is assumed they are hydraulically similar to heavier particles largely because their streamlined shape and surface smoothness offer less resistance to flow.

20. Although the highly irregular distribution of oolites in of fshore shelf samples is probably largely related (as in the beach deposits) to selective sorting, no pattern can be discerned; neither bottom topography nor substrate character shows any systematic relationship to oolite frequency and distribution. Possibly some oolites were deposited on the shelf during the Holocene transgression when lower relative sea level would have been more favorable for transport from shelf edge sources. Subsequently, modern shelf processes may have modified recent barrier deposits or added new material from 
farther seaward under a variable set of environmental conditions.

\section{Sources of 0olites}

21. Outcrops of oolite sediment and rocks have been reported from the Atlantic continental shelf off Florida by Terlecky (1967); Pilkey, Field, and Duane (1969); Macintyre and Milliman (1970); Meisburger and Duane (1971), and Pilkey and Field (1972). These deposits are probably of Pleistocene age and seem likely to be the ultimate source for oolites occurring on adjacent beaches and in Holocene shelf sediments. Other outcrops of presumable Pleistocene calcareous sediments also occur on the shelf but do not contain oolites.

22. While some of the oolites found on the beaches may have come directly from an exposure of oolitic material, most probably came from secondary sources in Holocene shelf sediments in which they had been deposited by reworking of older oolitic deposits.

23. Another possible source of oolites in beach sediment are rocks of the Anastasia Formation, a Pleistocene coquina that underlies the coast north of Boca Raton with occasional surface outcrops. The mechanical and biological breakdown of these rocks appears to make a substantial contribution to beach deposits. To examine this possibility, pieces of rock cast up on the beach and outcrop sample were obtained and checked for oolites. Though present, they are rare in the Anastasia rocks, and it seems unlikely that more than a small fraction of the oolites could have come from this source.

24. South of Boca Raton, the coast is underlain by the Miami oolite, a possible source of oolites in the beaches. However, this occurrence would require northward movement of material; and in the reach of coast covered by this study, the predominant drift is southward. In addition there is no significant trend of progressively decreasing abundance from south to north as might be expected if a point source at the south end of the study were making a significant contribution. It seems probable, therefore, that all of the oolites in beach deposits are coming from continental shelf sources.

\section{Quantitative Estimates}

25. A principal objective of this study is to evaluate the feasibility 
of using oolite frequency data to estimate the amount of non-oolite particles that are eroded and transported with the oolites. These data would be of value in sediment budget calculations because they would allow a quantitative estimate of total sediment contribution from a given source. Such a procedure seems reasonable if non-oolitic particles in the same size range as oolites are eroded and transported with oolites in the same proportional relationship that exists in source deposits. However, as previously discussed, oolitic particles seem to be subject to selective sorting due mainly to their shape and surface texture. It is therefore likely that their proportional relationship to non-oolitic particles in the source would undergo change in the course of erosion, transportation, and deposition at a new site.

26. Other factors must also be taken into consideration. These factors are the number of oolites present in a sample and the uniformity of their distribution in the immediate source and in the deposit areas.

27. In regard to the first factor, there are in most places sampled onshore and offshore a very small percentage of oolites relative to the associated non-oolitic particles. As a consequence, small random variations in oolitic concentrations can have a large effect on the estimated amount of non-oolitic material that would accompany the oolites to a given depositional site.

28. Secondly, Tables 2, 3, and 4 illustrate the nonuniform character of oolite distribution on the shelf. From any point on shore, it is possible that oolites could come ashore from many potential immediate sources on the shelf as periodic variations in wave direction and current patterns occur. It seems likely, in view of the irregular distribution of oolites on the shelf, that most of the potential sources would have various oolite concentrations.

29. A similar condition also occurs in the beach deposits where oolites are irregularly distributed (Table 1). Although some generalized distinction can be made between oolite frequency in backshore as compared to foreshore deposits, there is no way of knowing where oolite frequency actually represents the amount of oolites being brought ashore.

30. In view of the various difficulties discussed above, it is concluded that although oolites are useful natural tracers in indicating source areas of a beach or other sedimentary deposit, there is no feasible method of using oolite frequency data to estimate the total quantity of sediment coming from that source. 
31. Oolites occur on beaches of the Atlantic coast of Florida from Cape Canaveral to at least as far south as Boca Raton. Oolites also occur in Pleistocene and Holocene sediment and rock on the adjacent continental shelf. These shelf deposits appear to be the primary source of oolites for the beaches, thus indicating onshore transport.

32. The distribution of oolites in beaches is not uniform either alongshore or cross-shore. Sets of samples along beach profiles show that the oolites are significantly more numerous in backshore deposits than in foreshore deposits.

33. The distribution of oolites in Holocene sediments that cover most of the shelf is highly irregular and shows no apparent relationship to either shelf topography or sediment lithology. Core samples show a similar irregularity of oolite concentration in depth.

34. The irregular oolite distribution in beach and offshore deposits is apparently due to selective sorting. It is believed that this sorting occurs because the streamlined shape and surface smoothness of oolite cause them to respond to flow as particles heavier than the associated quartz and shell particles of the same size range.

35. Due to the small number of oolites in each sample, their susceptibility to selective sorting, and their irregular distribution in source and deposit areas, it is concluded that quantitative estimates of sediment transport on the basis of oolite frequency data are not feasible. 
REFERENCES

Field, Michael E., and Duane, David B. 1974. "Geomorphology and Sediments of the Inner Continental Shelf, Cape Canaveral, Florida," Technical Memorandum 42, US Army Engineer Waterways Experiment Station, Coastal Engineering Research Center, Vicksburg, MS.

Giles, Robert T., and Pilkey, Orrin H. 1965. "Atlantic Beach and Dune Sediments of the Southern United States," Journal of Sedimentary Petrology, Vo1 35, pp 900-910.

Macintyre, Ian G., and Milliman, John D. 1970. "Physiographic Features on the Outer Shelf and Upper Slope," Atlantic Continental Margin, Southeastern United States, Bulletin of the Geological Society of America, Vol 81 , pp 2577-2598.

Meisburger, Edward P., and Duane, David B. 1971. "Geomorphology and Sediments of the Inner Continental Shelf, Palm Beach to Cape Kennedy, Florida," Technical Memorandum No. 34, US Army Engineer Waterways Experiment Station, Coastal Engineering Research Center, Vicksburg, MS.

Meza, M. P., and Paola, C. R. 1977. "Evidence for Onshore Deposition of Pleistocene Continental Shelf Clays," Marine Geology, Vo1 23, pp M27-M35.

Pilkey, Orrin H., Blackwelder, Blake W., Doyle, L. V., Estes, E., and Terlecky, P. M. 1969. "Aspects of Carbonate Sedimentation of the Atlantic Continental Shelf of the Southern United States," Journal of Sedimentary Petrology, Vo1 39, pp 744-768.

Pilkey, Orrin H., and Field, Michael E. 1972. "Onshore Transportation of Continental Shelf Sediments: Atlantic Southeastern United States," in D. J. P. Swift, D. B. Duane, and 0. H. Pilkey, eds., Shelf Sediment Transport: Process and Pattern, Dowden, Hutchison, and Ross, Straudsburg, PA.

Pizzuto, James E. 1986. "Barrier Island Migration and Onshore Sediment Transport, Southwestern Delaware Bay, Delaware, USA," Marine Geology, Vo1 71, pp 299-325.

Terlecky, P. M. 1967. "The Nature and Distribution of Oolites on the Atlantic Continental Shelf off the Southeastern United States," M.S. Thesis, Duke University, Durham, NC.

Williams, S. Jeffres, and Meisburger, Edward P. 1987. "Sand Sources for the Transgressive Barrier Coast at Long Island, New York: Evidence for Landward Transport of Shelf Sediments," Proceedings, Coastal Sediments '87, American Society of Civil Engineers (in press). 
Table 1

Number of Oolites per 0.25 Grams of Sample in Beach Samples

\begin{tabular}{|c|c|c|c|c|c|}
\hline Site & Berm & Hole & Backshore & Backrush & Uprush \\
\hline $\begin{array}{lll}15 & \text { Fla } & 82 \\
16 & & \\
17 & & \\
11 & & \\
12 & & \end{array}$ & $\begin{array}{r}34.8 \\
8.3 \\
24.2 \\
20.0 \\
5.7\end{array}$ & $\begin{array}{l}-- \\
-- \\
-- \\
--\end{array}$ & $\begin{array}{c}17.7 \\
23.6 \\
-- \\
43.8 \\
10.7\end{array}$ & $\begin{array}{r}11.3 \\
0.2 \\
10.4 \\
5.4 \\
5.8\end{array}$ & $\begin{array}{c}4.8 \\
2.6 \\
-- \\
25.5 \\
6.8\end{array}$ \\
\hline $\begin{array}{l}18 \\
13 \\
19 \\
20 \\
21\end{array}$ & $\begin{array}{r}36.2 \\
21.3 \\
14.4 \\
22.0 \\
9.4\end{array}$ & $\begin{array}{c}-- \\
-- \\
26.8 \\
38.8 \\
69.7\end{array}$ & $\begin{array}{c}-- \\
20.2 \\
-- \\
36.0 \\
--\end{array}$ & $\begin{array}{r}9.0 \\
9.7 \\
5.4 \\
11.1 \\
8.2\end{array}$ & $\begin{array}{c}11.4 \\
-- \\
4.6 \\
9.2 \\
10.6\end{array}$ \\
\hline $\begin{array}{l}22 \\
23 \\
24 \\
25 \\
26\end{array}$ & $\begin{array}{r}16.0 \\
18.9 \\
12.7 \\
11.4 \\
3.8\end{array}$ & $\begin{array}{c}7.7 \\
20.0 \\
24.4 \\
-- \\
35.0\end{array}$ & $\begin{array}{r}35.7 \\
20.2 \\
35.5 \\
21.2 \\
8.9\end{array}$ & $\begin{array}{l}2.1 \\
3.3 \\
6.5 \\
1.4 \\
3.9\end{array}$ & $\begin{array}{l}4.3 \\
6.0 \\
7.6 \\
6.9 \\
3.8\end{array}$ \\
\hline $\begin{array}{l}27 \\
28 \\
29 \\
30 \\
31\end{array}$ & $\begin{array}{r}24.2 \\
F \perp 11 \\
25.7 \\
23.8 \\
8.8\end{array}$ & $\begin{array}{c}27.6 \\
-- \\
25.0 \\
20.3 \\
16.5\end{array}$ & $\begin{array}{c}28.8 \\
-- \\
12.5 \\
18.8 \\
46.8\end{array}$ & $\begin{array}{l}6.3 \\
-- \\
5.7 \\
1.3 \\
2.8\end{array}$ & $\begin{array}{l}6.4 \\
-- \\
3.7 \\
3.9 \\
5.8\end{array}$ \\
\hline $\begin{array}{l}32 \\
33 \\
34 \\
35 \\
36\end{array}$ & $\begin{array}{r}15.2 \\
33.8 \\
35.8 \\
9.6 \\
32.8\end{array}$ & $\begin{array}{c}45.8 \\
-- \\
58.3 \\
60.0 \\
--\end{array}$ & $\begin{array}{r}73.3 \\
7.4 \\
31.0 \\
41.8 \\
--\end{array}$ & $\begin{array}{l}1.9 \\
8.2 \\
5.9 \\
8.0 \\
9.0\end{array}$ & $\begin{array}{c}6.1 \\
-- \\
24.3 \\
9.7 \\
14.3\end{array}$ \\
\hline $\begin{array}{r}37 \\
6 \\
7 \\
8 \\
9\end{array}$ & $\begin{array}{c}12.2 \\
18.81 \\
11.0 \\
1.2 \\
\text { Fi11 }\end{array}$ & $\begin{array}{c}78.3 \\
-- \\
-- \\
-- \\
--\end{array}$ & $\begin{array}{c}37.8 \\
37.5 \\
25.9 \\
16.8 \\
--\end{array}$ & $\begin{array}{r}5.9 \\
13.0 \\
2.7 \\
-- \\
--\end{array}$ & $\begin{array}{c}15.0 \\
11.3 \\
10.3 \\
5.0 \\
--\end{array}$ \\
\hline $\begin{array}{r}10 \\
5 \\
4 \\
3 \\
2\end{array}$ & $\begin{array}{c}\text { Fil1 } \\
17.2 \\
0 \\
1.4 \\
3.1\end{array}$ & $\begin{array}{l}-- \\
-- \\
-- \\
-- \\
--\end{array}$ & $\begin{array}{r}-- \\
32.0 \\
1.2 \\
0.9 \\
2.3\end{array}$ & $\begin{array}{c}-- \\
13.2 \\
0 \\
1.3 \\
1.6\end{array}$ & $\begin{array}{l}-- \\
-- \\
-- \\
-- \\
--\end{array}$ \\
\hline $\begin{array}{r}1 \\
40 \\
39 \\
38 \\
42\end{array}$ & $\begin{array}{l}1.8 \\
0.6 \\
2.7 \\
3.2 \\
0\end{array}$ & $\begin{array}{l}-- \\
1.9 \\
3.5 \\
0\end{array}$ & $\begin{array}{l}0 \\
1.2 \\
2.3 \\
2.9 \\
0.7\end{array}$ & $\begin{array}{l}1.0 \\
1.1 \\
2.1 \\
0 \\
0\end{array}$ & $\begin{array}{l}-- \\
1.7 \\
0.8 \\
0.7 \\
0\end{array}$ \\
\hline $\begin{array}{l}41 \\
43\end{array}$ & $\begin{array}{l}0 \\
0\end{array}$ & $\begin{array}{l}0 \\
0\end{array}$ & $\begin{array}{l}0.5 \\
0\end{array}$ & $\begin{array}{l}0.5 \\
0\end{array}$ & $\begin{array}{l}0.7 \\
--\end{array}$ \\
\hline
\end{tabular}


Table 2

Oolite Frequency in the Cape Canaveral Area

\begin{tabular}{|c|c|c|c|}
\hline Core No. & No. of Oolites* & Sample Weight, g & No. per $0.25 \mathrm{~g}$ \\
\hline $\begin{array}{l}91 \\
92 \\
92 \\
94 \\
95\end{array}$ & $\begin{array}{r}111 \\
12 \\
122 \\
159 \\
58\end{array}$ & $\begin{array}{l}0.25 \\
0.25 \\
0.08 \\
0.06 \\
0.22\end{array}$ & $\begin{array}{r}111.0 \\
12.0 \\
318.3 \\
662.5 \\
66.0\end{array}$ \\
\hline $\begin{array}{c}96 \\
97 * \\
98 \\
99 \\
100\end{array}$ & $\begin{array}{r}45 \\
-- \\
3 \\
12 \\
4\end{array}$ & $\begin{array}{c}0.14 \\
-. \\
0.16 \\
0.08 \\
0.07\end{array}$ & $\begin{array}{c}80.3 \\
-- \\
4.7 \\
37.5 \\
14.3\end{array}$ \\
\hline $\begin{array}{l}101 * \\
102 \\
103 \\
104 \\
105\end{array}$ & $\begin{array}{r}-- \\
7 \\
12 \\
28 \\
44\end{array}$ & $\begin{array}{l}-- \\
0.09 \\
0.19 \\
0.08 \\
0.08\end{array}$ & $\begin{array}{r}-- \\
19.4 \\
15.8 \\
87.5 \\
137.5\end{array}$ \\
\hline $\begin{array}{l}106 \\
107 \\
108 * \\
109 \\
110\end{array}$ & $\begin{array}{r}112 \\
84 \\
-- \\
1 \\
2\end{array}$ & $\begin{array}{c}0.19 \\
0.06 \\
-- \\
0.08 \\
0.35\end{array}$ & $\begin{array}{c}147.3 \\
350.0 \\
-- \\
3.1 \\
1.4\end{array}$ \\
\hline $\begin{array}{l}111 \\
112 \\
113 \\
114 \\
115\end{array}$ & $\begin{array}{r}0 \\
117 \\
21 \\
12 \\
5\end{array}$ & $\begin{array}{l}0.09 \\
0.24 \\
0.28 \\
0.16 \\
0.05\end{array}$ & $\begin{array}{c}0 \\
122.0 \\
18.8 \\
18.8 \\
25.0\end{array}$ \\
\hline $\begin{array}{l}116 \\
117 * \\
118 \\
119 \\
120\end{array}$ & $\begin{array}{r}111 \\
-- \\
21 \\
167 \\
8\end{array}$ & $\begin{array}{c}0.07 \\
-. \\
0.11 \\
0.09 \\
0.11\end{array}$ & $\begin{array}{r}397.5 \\
-- \\
47.8 \\
465.0 \\
18.2\end{array}$ \\
\hline $\begin{array}{l}121 \\
122 \\
123 \\
124 \\
125\end{array}$ & $\begin{array}{l}24 \\
21 \\
12 \\
26 \\
16\end{array}$ & $\begin{array}{l}0.22 \\
0.15 \\
0.17 \\
0.09 \\
0.13\end{array}$ & $\begin{array}{l}27.3 \\
35.0 \\
17.6 \\
72.3 \\
30.8\end{array}$ \\
\hline $\begin{array}{l}126 \\
127 * \\
128 \\
129 \\
130\end{array}$ & $\begin{array}{r}27 \\
-- \\
11 \\
3 \\
1\end{array}$ & $\begin{array}{c}0.08 \\
-- \\
0.11 \\
0.27 \\
0.16\end{array}$ & $\begin{array}{c}84.3 \\
-- \\
25.0 \\
2.8 \\
1.5\end{array}$ \\
\hline \multicolumn{4}{|c|}{ (Continued) } \\
\hline
\end{tabular}

* No oolite data available from core. 
Table 2 (Continued)

\begin{tabular}{|c|c|c|c|}
\hline Core No. & No. of Oolites* & Sample Weight, g & No. per $0.25 \mathrm{~g}$ \\
\hline $\begin{array}{l}131 \\
132 \\
133 \\
134 \\
135\end{array}$ & $\begin{array}{l}28 \\
14 \\
-- \\
69 \\
74\end{array}$ & $\begin{array}{c}0.10 \\
0.10 \\
-- \\
0.17 \\
0.24\end{array}$ & $\begin{array}{r}70.0 \\
35.0 \\
-- \\
101.5 \\
77.0\end{array}$ \\
\hline $\begin{array}{l}136 \\
137 \\
138 \\
139 \\
140\end{array}$ & $\begin{array}{r}10 \\
90 \\
27 \\
73 \\
154\end{array}$ & $\begin{array}{l}0.14 \\
0.22 \\
0.23 \\
0.33 \\
0.11\end{array}$ & $\begin{array}{r}17.9 \\
102.3 \\
29.3 \\
55.3 \\
350.0\end{array}$ \\
\hline $\begin{array}{l}141 \\
142 \\
143 \\
144 \\
145\end{array}$ & $\begin{array}{r}121 \\
88 \\
75 \\
83 \\
55\end{array}$ & $\begin{array}{l}0.12 \\
0.24 \\
0.08 \\
0.27 \\
0.28\end{array}$ & $\begin{array}{r}252.0 \\
91.8 \\
234.5 \\
76.8 \\
49.1\end{array}$ \\
\hline $\begin{array}{l}146 \\
147 \\
148 \\
149 * \\
150\end{array}$ & $\begin{array}{l}49 \\
22 \\
13 \\
-- \\
92\end{array}$ & $\begin{array}{c}0.16 \\
0.24 \\
0.24 \\
-- \\
0.16\end{array}$ & $\begin{array}{c}76.5 \\
22.9 \\
13.5 \\
-- \\
143.8\end{array}$ \\
\hline $\begin{array}{l}151 \\
152 \\
153 \\
154 \\
155\end{array}$ & $\begin{array}{r}-- \\
118 \\
117 \\
1 \\
1\end{array}$ & $\begin{array}{l}-- \\
0.23 \\
0.14 \\
0.21 \\
0.17\end{array}$ & $\begin{array}{r}-- \\
128.3 \\
209.0 \\
1.2 \\
1.5\end{array}$ \\
\hline $\begin{array}{l}156 \\
157 \\
158 \\
159 \\
160 *\end{array}$ & $\begin{array}{r}1 \\
7 \\
6 \\
2 \\
--\end{array}$ & $\begin{array}{c}0.21 \\
0.26 \\
0.31 \\
0.20 \\
\ldots\end{array}$ & $\begin{array}{l}1.2 \\
7.0 \\
4.8 \\
2.5 \\
--\end{array}$ \\
\hline $\begin{array}{l}161 * \\
162 \\
163 \\
164 \\
165\end{array}$ & $\begin{array}{r}-- \\
6 \\
7 \\
7 \\
3\end{array}$ & $\begin{array}{l}-- \\
0.22 \\
0.20 \\
0.21 \\
0.24\end{array}$ & $\begin{array}{l}-- \\
6.8 \\
8.8 \\
8.3 \\
3.1\end{array}$ \\
\hline $\begin{array}{l}166 \\
167 \\
168 \\
169 \\
170\end{array}$ & $\begin{array}{r}3 \\
45 \\
28 \\
0 \\
10\end{array}$ & $\begin{array}{c}0.34 \\
0.21 \\
0.23 \\
- \\
0.10\end{array}$ & $\begin{array}{c}2.2 \\
53.5 \\
30.4 \\
-- \\
25.0\end{array}$ \\
\hline
\end{tabular}

* No oolite data available from core.

(Sheet 2 of 3 ) 
Table 2 (Concluded)

\begin{tabular}{|c|c|c|c|}
\hline Core No. & No. of 0olites* & Sample Weight, g & No. per $0.25 \mathrm{~g}$ \\
\hline 171 & 8 & 0.27 & 7.4 \\
\hline 172 & 0 & -- & -- \\
\hline 173 & 15 & 0.20 & 18.8 \\
\hline 174 & 26 & 0.17 & 38.3 \\
\hline 175 & - & -- & -- \\
\hline 176 & 19 & 0.25 & 19.0 \\
\hline 177 & 2 & 0.17 & 2.9 \\
\hline $178 *$ & -- & -- & -- \\
\hline 191 & 104 & 0.14 & 185.0 \\
\hline 192 & 169 & 0.18 & 234.8 \\
\hline 193 & 13 & 0.15 & 21.7 \\
\hline 194 & - & -- & -- \\
\hline
\end{tabular}

* No oolite data available from core.

(Sheet 3 of 3 ) 
Table 3

Oolite Frequency in the Fort Pierce Area

\begin{tabular}{|c|c|c|c|}
\hline Core No. & No. of Oolites & Sample Weight, g & No. per $0.25 \mathrm{~g}$ \\
\hline 32 & 8 & 0.17 & 11.8 \\
\hline $33 *$ & -- & - & -- \\
\hline 34 & 127 & 0.05 & 635.0 \\
\hline 35 & 11 & 0.12 & 22.9 \\
\hline 36 & 19 & 0.12 & 39.5 \\
\hline 37 & 43 & 0.09 & 119.3 \\
\hline 38 & 13 & 0.17 & 19.1 \\
\hline $39 *$ & -- & -- & -- \\
\hline 40 & 25 & 0.10 & 62.5 \\
\hline 41 & 5 & 0.16 & 7.8 \\
\hline 42 & 21 & 0.12 & 43.7 \\
\hline 43 & 3 & 0.17 & 4.4 \\
\hline 44 & -- & -- & -- \\
\hline 45 & 20 & 0.15 & 33.3 \\
\hline 46 & 50 & 0.28 & 44.8 \\
\hline 47 & 36 & 0.20 & 45.0 \\
\hline 48 & 48 & 0.12 & 100.0 \\
\hline 49 & 112 & 0.04 & 700.0 \\
\hline 50 & 54 & 0.18 & 75.0 \\
\hline 51 & 5 & 0.07 & 17.9 \\
\hline 52 & 2 & 0.07 & 7.1 \\
\hline 53 & 92 & 0.25 & 92.0 \\
\hline 54 & 127 & 0.07 & 453.6 \\
\hline 55 & 14 & 0.14 & 25.0 \\
\hline 56 & 2 & 0.07 & 7.2 \\
\hline 57 & 8 & 0.09 & 22.2 \\
\hline 58 & 179 & 0.14 & 320.0 \\
\hline 59 & 47 & 0.05 & 235.0 \\
\hline 60 & 38 & 0.02 & 475.0 \\
\hline 61 & 33 & 0.52 & 15.9 \\
\hline $62 *$ & -- & -- & -- \\
\hline 63 & 39 & 0.26 & 37.5 \\
\hline 64 & 127 & 0.18 & 176.5 \\
\hline 65 & 116 & 1.18 & 161.0 \\
\hline 66 & 160 & 0.08 & 500.0 \\
\hline 67 & 7 & 0.23 & 7.6 \\
\hline 68 & 31 & 0.24 & 32.3 \\
\hline 69 & 238 & 0.17 & 350.0 \\
\hline 70 & 46 & 0.09 & 127.8 \\
\hline 71 & 64 & 0.16 & 88.8 \\
\hline
\end{tabular}

* No oolite data available from core. 
Table 3 (Concluded)

\begin{tabular}{cccc}
\hline Core No. & No. of Dolites & Sample Weight, g & No. per $0.25 \mathrm{~g}$ \\
\cline { 2 - 4 } 72 & 95 & 0.06 & 395.0 \\
73 & 90 & 0.16 & 140.8 \\
74 & 6 & 0.06 & 25.0 \\
75 & 165 & 0.12 & 343.8 \\
76 & 10 & 0.13 & 19.2 \\
77 & 53 & 0.21 & 63.0 \\
78 & 13 & 0.21 & 15.5 \\
79 & 19 & 0.27 & 17.6 \\
80 & 91 & 0.05 & 455.0 \\
81 & 3 & 0.17 & 4.4 \\
$82 *$ & -- & -- & - \\
83 & 6 & 0.13 & 11.5 \\
$84 *$ & -- & -- & -- \\
85 & - & 0.17 & 50.0 \\
86 & 34 & 0.17 & 16.2 \\
87 & 11 & 0.24 & 117.5 \\
88 & 113 & 0.13 & 11.5 \\
89 & 6 & 0.20 & 21.3 \\
90 & 17 & 0.18 & 55.5
\end{tabular}

* No oolite data available from core. 
Table 4

Comparison of Core Top and Downhole Samples

\begin{tabular}{|c|c|c|c|}
\hline Core No. & Interval, $\mathrm{ft}$ & Oolites per $0.25 \mathrm{~g}$ & Lithology* \\
\hline 32 & 0 & 11.8 & - \\
\hline 32 & -6 & 32.3 & $S$ \\
\hline 34 & 0 & 635.0 & -- \\
\hline 34 & -7 & 111.0 & 0 \\
\hline 38 & 0 & 19.1 & - \\
\hline 38 & -9 & 4.4 & $\mathrm{~S}$ \\
\hline 40 & 0 & 62.5 & - \\
\hline 40 & -8 & 28.3 & 0 \\
\hline 43 & 0 & 4.4 & -- \\
\hline 43 & -8 & 1.6 & $\mathrm{~S}$ \\
\hline 43 & -10 & 20.8 & 0 \\
\hline 46 & 0 & 44.8 & -- \\
\hline 46 & -5 & 32.8 & 0 \\
\hline 48 & 0 & 100.0 & -- \\
\hline 48 & -4 & 227.0 & 0 \\
\hline 48 & -9 & 73.8 & 0 \\
\hline 49 & 0 & 700.0 & -- \\
\hline 49 & -5 & 53.5 & 0 \\
\hline 50 & 0 & 75.0 & -- \\
\hline 50 & -8 & 10.0 & S \\
\hline 53 & 0 & 92.0 & -- \\
\hline 53 & -10 & 41.8 & 0 \\
\hline 54 & 0 & 452.5 & -- \\
\hline 54 & -4 & 5.0 & 0 \\
\hline 61 & 0 & 15.9 & -- \\
\hline 61 & -10 & 26.9 & 0 \\
\hline 63 & 0 & 37.5 & -- \\
\hline 63 & 6 & 58.0 & $S$ \\
\hline 64 & 0 & 176.5 & - \\
\hline 64 & -9 & 20.3 & 0 \\
\hline 66 & 0 & 500.0 & -- \\
\hline 66 & 8 & 8.3 & 0 \\
\hline 68 & 0 & 32.3 & -- \\
\hline 68 & 9 & 11.4 & $\mathrm{~S}$ \\
\hline 75 & 0 & 343.8 & - \\
\hline 75 & -4 & 227.3 & 0 \\
\hline 75 & -9 & 253.5 & 0 \\
\hline
\end{tabular}

(Continued)

* $S$ = Same 1ithology as top sample.

$0=$ Different 1ithology from top sample.

(Sheet 1 of 3 ) 
Table 4 (Continued)

\begin{tabular}{|c|c|c|c|}
\hline Core No. & Interva1, ft & Oolites per $0.25 \mathrm{~g}$ & Lithology \\
\hline 76 & 0 & 19.5 & -- \\
\hline 76 & -7 & 39.3 & 0 \\
\hline 88 & 0 & 11.5 & -- \\
\hline 88 & -3 & 23.2 & 0 \\
\hline 93 & 0 & 508.3 & -- \\
\hline 93 & -7 & 149.0 & - \\
\hline 94 & 0 & 662.5 & - \\
\hline 94 & -3 & 237.5 & 0 \\
\hline 95 & 0 & 66.0 & -- \\
\hline 95 & -4 & 213.8 & 0 \\
\hline 95 & -6 & 77.0 & 0 \\
\hline 103 & 0 & 15.8 & - \\
\hline 103 & -8 & 29.3 & 0 \\
\hline 106 & 0 & 147.3 & - \\
\hline 106 & -6 & 153.3 & $S$ \\
\hline 107 & 0 & 350.0 & -- \\
\hline 107 & -8 & 111.5 & 0 \\
\hline 109 & 0 & 3.1 & -- \\
\hline 109 & -7 & 2.0 & 0 \\
\hline 112 & 0 & 122.0 & - \\
\hline 112 & 8 & 4.4 & 0 \\
\hline 116 & 0 & 397.5 & -. \\
\hline 116 & -9 & 252.5 & $\mathrm{~S}$ \\
\hline 118 & 0 & 47.8 & - \\
\hline 118 & -5 & 125.0 & 0 \\
\hline 119 & 0 & 465.0 & -- \\
\hline 119 & -6 & 450.0 & -- \\
\hline 120 & 0 & 18.2 & -- \\
\hline 120 & -5 & 95.0 & -- \\
\hline 120 & -7 & 65.6 & 0 \\
\hline 122 & 0 & 35.0 & -- \\
\hline 122 & -8 & 46.8 & $\mathrm{~S}$ \\
\hline 125 & 0 & 30.8 & -- \\
\hline 125 & 0 & 30.8 & - \\
\hline 125 & -6 & 44.5 & $\mathrm{~S}$ \\
\hline 125 & -8 & 18.2 & 0 \\
\hline 126 & 0 & 84.3 & -- \\
\hline 126 & -9 & 1.5 & 0 \\
\hline 128 & 0 & 25.0 & - \\
\hline 128 & -8 & 13.4 & $\mathrm{~S}$ \\
\hline 129 & 0 & 2.8 & -- \\
\hline 129 & -8 & 7.6 & S \\
\hline 131 & 0 & 70.0 & - \\
\hline \multirow[t]{2}{*}{131} & -7 & 114.0 & $\mathrm{~S}$ \\
\hline & & nued) & et 2 of 3 ) \\
\hline
\end{tabular}


Table 4 (Concluded)

\begin{tabular}{crrr}
\hline Core No. & Interval, ft & Oolites per $0.25 \mathrm{~g}$ & \multicolumn{1}{c}{ Lithology } \\
\cline { 2 - 4 } 131 & -1 & 91.8 & 0 \\
135 & 0 & 77.0 & -- \\
135 & -7 & 66.3 & 0 \\
138 & 0 & 29.3 & 0 \\
138 & -10 & 81.5 & -- \\
140 & 0 & 350.0 & 0 \\
140 & -5 & 13.5 & - \\
143 & 0 & 234.5 & 0 \\
143 & -8 & 175.0 & -- \\
146 & 0 & 76.5 & $\mathrm{~S}$ \\
146 & -3 & 9.8 & -- \\
147 & 0 & 22.9 & 0 \\
147 & -5 & 21.2 & - \\
159 & 0 & 21.4 & $\mathrm{~S}$ \\
159 & -10 & 42.5 & - \\
165 & 0 & 3.1 & $\mathrm{~S}$ \\
165 & -11 & 2.7 & -- \\
167 & 0 & 53.5 & $\mathrm{~S}$ \\
167 & -5 & 26.0 & 0
\end{tabular}


Table 5

Oolite Concentration Before and After Panning

\begin{tabular}{|c|c|c|c|c|c|c|}
\hline \multirow{3}{*}{$\begin{array}{l}\text { Site and } \\
\text { Location }\end{array}$} & \multicolumn{3}{|c|}{ Subsample 1-Normal } & \multicolumn{3}{|c|}{ Subsample 2-Pan Residue } \\
\hline & Oolite & Wt* & No. in & Oolite & Wt* & No. in \\
\hline & Count & $g$ & $0.25 \mathrm{~g}$ & Count & $\mathrm{g}$ & $\underline{0.25 \mathrm{~g}}$ \\
\hline 1 backrush & 2 & 0.50 & 1 & 2 & 0.34 & 1.5 \\
\hline 5 backrush & 48 & 0.91 & 13.2 & 28 & 0.26 & 26.9 \\
\hline 7 berm & 25 & 0.57 & 10.9 & 5 & 0.18 & 20.8 \\
\hline 11 backrush & 11 & 0.51 & 5.4 & 32 & 0.25 & 32.0 \\
\hline 11 berm & 36 & 0.45 & 20.0 & 110 & 0.29 & 94.8 \\
\hline 13 backshore & 42 & 0.52 & 20.2 & 44 & 0.46 & 23.9 \\
\hline 16 uprush & 5 & 0.49 & 2.6 & 10 & 0.38 & 6.6 \\
\hline 16 backshore & 34 & 0.36 & 23.6 & 52 & 0.33 & 39.5 \\
\hline 18 berm & 77 & 0.53 & 36.3 & 71 & 0.24 & 74.0 \\
\hline 21 hole & 34 & 0.33 & 25.8 & 46 & 0.27 & 42.5 \\
\hline 24 uprush & 13 & 0.43 & 7.6 & 73 & 0.53 & 34.5 \\
\hline 25 uprush & 12 & 0.43 & 7.0 & 50 & 0.42 & 29.8 \\
\hline 26 uprush & 6 & 0.40 & 3.8 & 33 & 0.47 & 17.6 \\
\hline 27 uprush & 11 & 0.43 & 6.4 & 17 & 0.26 & 16.3 \\
\hline 27 backshore & 47 & 0.41 & 28.8 & 119 & 0.26 & 114.5 \\
\hline 29 backrush & 8 & 0.36 & 5.6 & 23 & 0.26 & 22.1 \\
\hline 29 hole & 50 & 0.54 & 23.2 & 98 & 0.27 & 90.8 \\
\hline 32 berm & 28 & 0.46 & 15.2 & 73 & 0.33 & 55.3 \\
\hline
\end{tabular}

* Wt $=$ weight of sample. 